Piotr Zamojski

ORCID: 0000-0002-5505-7579

https://doi.org/10.26881/ae.2019.16.07

Uniwersytet Gdański

piotr.zamojski@ug.edu.pl

\title{
Ponieważ sprawy są ulotne, trzeba mieć wprawne oko
}

Joanna Rutkowiak stawia kwestię umasowienia szkolnictwa wyższego w sposób, który odbiega od typowych ujęć tej sprawy. Nie jest to bowiem ani wyraz konserwatywnej nostalgii za elitarnym uniwersytetem, ani lewicowa pochwała otwierania się edukacji wyższej na ludzi dotąd z niej wykluczonych, ani też - naturalnie neoliberalna narracja o wolnym rynku akademickich usług edukacyjnych dla każdego chętnego. Zamiast tego jest to opowieść o odpowiedzialności uczonej wobec studentów kulturowo, społecznie i ekonomicznie biednych, przede wszystkim zaś radykalnie innych od świata uniwersytetu, z którym niekiedy spektakularnie się zderzają. Są to kolizje potężne, które czynią zarówno świat akademicki, jak i owych studentów oniemiałymi w tym sensie, że pozwalają obu stronom doświadczyć braku wspólnych punktów odniesienia, niezdolności do rozmowy, funkcjonowania w innych rejestrach.

Zakładam oczywiście, że historia Rutkowiak może toczyć się i - zapewne zazwyczaj toczy się inaczej. Nikt się z nikim nie zderza, ale funkcjonuje obok siebie, zaspokajając swoje interesy w jak najmniej kosztowny sposób. Analiza autorki pokazuje dojmująco, że to właśnie pojawienie się świata akademickiego, czyli wydarzenie się „universitas”, generuje kolizje. Pozostaje natomiast w tej analizie niedopowiedziane to, że wydarzanie się ,universitas” wymaga podjęcia przez akademików odpowiedzialności za wspólny świat i za studiujących (czy też raczej za tych, którzy mieliby studiować), co wiąże się z niebagatelnym, nieustępliwym, długotrwałym wysiłkiem działania zgodnego z założeniem o równości inteligencji. Narracja Rutkowiak jest opowieścią siłaczki, która najpierw poważnie traktuje pracę dydaktyczną ze studentami i nie poddaje się presji podawania gotowych i radykalnie uproszczonych rezultatów procesów myślowych (zdatnych do bezmyślnego zapamiętania i zwrócenia na egzaminie), tylko podejmuje próby uruchamiania inteligencji studentów, to jest podejmuje próby wspólnego myślenia. Następnie 
zaś nieustępliwie obstaje przy akademickich wymaganiach egzaminacyjnych. Nie odpuszcza tych standardów, czyli pozostaje wierna założeniu o równości inteligencji.

Warto zauważyć, że nie jest to typowa Rancière’owska strategia wycofywania inteligencji nauczyciela czy mistrza tak, aby mogła się objawić inteligencja uczniów (Rancière 1991: 13). Rutkowiak nie jest ignorantką w Rancière'owskim sensie. Jest ekspertką. Jednak - jak sama stawia tę sprawę - ignoruje ignorancję swoich studentów, nie przyjmuje do wiadomości ich braków, a także nieakademickich nastawień czy pozapoznawczych interesów, i nie ustępuje w działaniach wypływających z założenia, wedle którego studenci ci mogą studiować, to jest mają taką samą inteligencję, jak ich nauczycielka, taką samą, jak autorzy koncepcji będących przedmiotem ich studiów, taką samą, jak wszyscy inni ludzie na ziemi. Mogą, są w stanie - trzeba jedynie wytrzymać napór ich przyzwyczajeń, przedsądów, zestalonych schematów percypowania, myślenia, działania, które ukształtowały się przez lata presji ze strony hegemonicznych dyskursów.

W tym rzecz - siłaczka jest w tym zupełnie sama wobec sił, które dalece ją przekraczają. Niespecjalnie przeziera to $\mathrm{z}$ tekstu, ale przecież nie jest to historia zupełnie wyjątkowa i w tym sensie nam nieznana. Poza opowieścią Żeromskiego, domyślamy się, że zarówno studenci, władze uczelni, jak i bliscy siłaczki nie są zadowoleni i być może nawet cierpią z powodu tego jej uporu, który dla niektórych może zakrawać na donkiszoterię (zob. Zamojski 2009). Niewątpliwie jest to historia budząca w czytelniku najwyższy podziw i szacunek, ale w nieunikniony sposób pojawia się pytanie o sens odpowiedzi, jaką daje Rutkowiak na pytanie o umasowienie edukacji wyższej: czy istnienie siłaczek wystarczy? Czy możemy tak postawić sprawę, że potrzeba nam siłaczek, że wszyscy powinniśmy się nimi stać?

Jednocześnie nie da się i nie wolno tak prosto oddalić stanowiska, które rysuje Rutkowiak, ponieważ chodzi w nim o coś więcej niż o wezwanie do odpowiedzialności i poświęcenia poszczególnych akademików. Autorka wskazuje na zarys możliwych praktyk edukacyjnych w sytuacji umasowienia edukacji akademickiej, a to oznacza, że wskazuje również na możliwy kierunek reorganizacji szkół wyższych. Chodziłoby zatem o instytucjonalne narzędzia wspierania nieustępliwej wierności założeniu o równości inteligencji. Rozwiązania te należałoby dopiero wymyślić, ale tekst Rutkowiak już wyznacza dla nich pewne parametry.

Z tego, co zdążyłem zauważyć, powyżej wyłania się pierwsza taka wskazówka: równość wymaga przemocy. Jest to stanowisko zbieżne z argumentacją Jacques’a Rancière’a, wedle którego to, co pozornie identyfikujemy jako różnicę inteligencji, jest de facto różnicą siły woli, samodyscypliny w studiowaniu (Rancière 1991: 55-57). Rutkowiak pośrednio przekonuje nas, że po długotrwałym i obezwładniającym treningu w demaskowaniu i demonizowaniu relacji władzy w procesach pedagogicznych czas pomyśleć o przemocy nauczycielskiej jako o mocy konstruktywnej (zob. Benjamin 2012). Przeciwko utartym dyskursom „odtwarzania nierówności” oraz „wyrównywania szans edukacyjnych” w opowieści autorki nauczycielka swoim odpowiedzialnym uporem wymuszała równość na studentach, którzy dążyli do 
odtwarzania nierówności. Zamiast zatem myśleć o unikaniu przemocy, o jej neutralizacji czy balansowaniu, Rutkowiak stawia problem jej ukierunkowania, czyli takiego jej formowania, żeby pozostawać w zgodzie z aksjomatem o równości inteligencji.

Jednak kluczowe - moim zdaniem - wskazówki, jakie nam daje autorka, ujawniają się dopiero wówczas, gdy przyglądamy się bliżej temu, jak bada ona swoją praktykę, czyli temu: na co patrzy, co przyciąga jej uwagę i co zauważa w tym, co dzieje się wokół niej (w sytuacjach uprawiania umasowionej edukacji wyższej). Są to mgnienia. Fraza rzucona przez „instruktorkę", która wyłania się znikąd i znika w tłumie, by nigdy nie ujawnić swojej tożsamości. Słowo wypowiedziane przez egzaminowanego „mechanika”. Pytanie postawione po wykładzie przez „wnuczkę baletnicy”. To właśnie w tych mgnieniach wydarza się równość, weryfikuje się aksjomat o równości inteligencji, ale też - jak chcę twierdzić - pokazuje się kształcenie. Naturalnie, trudność polega na tym, że mgnienia te łatwo przeoczyć. Trzeba być wyczulonym, uwrażliwionym na pozornie drobne, epizodyczne zdarzenia, w których rozpoznaje się wydarzanie kształcenia. Trzeba skrajnego skupienia uwagi na tym, co się dzieje, co i jak mówią i czynią studenci czy uczniowie, żeby móc to „złapać”, podjąć i pójść z nimi dalej. Trzeba być bardzo uważnym, żeby w typowej dla każdej sytuacji edukacyjnej gęstwinie interakcji móc wyłowić znaczące słowo, frazę, pytanie czy gest (vide „wymiana drapieżnika” i „błazen”), w których dochodzi do czegoś doniosłego edukacyjnie. W których studenci - zorientowawszy się, że chodzi o uruchamianie ich inteligencji - wprawiają ją w ruch, czyniąc się równymi. Ilu już nauczycieli przeoczyło i puściło mimo uszu prawdziwe edukacyjne wydarzenia? Na ile jeszcze jesteśmy strażnikami wydarzania się kształcenia? $\mathrm{Na}$ ile naprawdę potrafimy podejmować te ulotne sygnały, nieśmiałe zaczepienia, momentalne ujawnienia pracy inteligencji innego? Rutkowiak wyraźnie pokazuje, że kształcenia należy szukać w takich mgnieniach, że nie ma ono struktury powtarzalnych, algorytmicznych procedur produkujących zamierzone wcześniej rezultaty, ale właśnie daje nam znać o sobie, udziela się w najbardziej niespodziewanych, często jednorazowych chwilach. Naturalnie, do ich powstania niezbędna jest długotrwała, uparta i systematyczna praca: nieustępliwy wysiłek nauczycielskiej przemocy, działania zgodnego $z$ aksjomatem równości inteligencji. Jednak sens tej pracy daje o sobie znać w owych mgnieniach, a nie w jakichś zobiektywizowanych i policzalnych wskaźnikach efektywności.

Czym są zatem dla Rutkowiak te frazy, słowa i gesty? Sama zauważa, że są one „nosicielem nadziei, że udało się coś [wyróżnienie - P.Z.] osiągnąć”. Cóż się tutaj udaje? Czym jest owo coś? Kolejna wskazówka dotyczy właśnie charakteru edukacyjnych osiągnięć. To, co osiąga się w kształceniu, jest efemeryczne, sporadyczne i momentalne. Daje o sobie znać w sposób, który wymaga wprawnego oka i skupienia uwagi na ulotnych momentach ujawniania się pracy równych inteligencji. Osiągnięcia edukacyjne to zatem tkanka niezwykle delikatna i łatwa nie tylko do przeoczenia, ale i zniszczenia (przez nieuwagę, niepodjęcie, zbagatelizowanie). Trzeba nie tylko wysilonej uwagi, ale także i taktu (Manen 1991), aby uchwycić 
to, co udało się osiągnąć, docenić i podjąć to w dalszej pracy. Nie jest to łatwe, ponieważ różne zewnętrzne miary sugerują, że osiągnięcia te są zawsze skromne. W przeciwieństwie chociażby do oświeceniowych ambicji, nie udaje się powoływać nowego, lepszego świata „wiecznego pokoju”. Udaje się „wmyśleć w metodologię”, „wymienić drapieżnika”, „dopytać się o coś dla babci baletnicy”. Jednakże, z perspektywy immanentnej dla logiki edukacji, każde z tych osiągnięć jest dokonaniem niemożliwego: uczynieniem się równym w nierównym społeczeństwie (zob. Rancière 1991: 133). Osiągnięcia edukacyjne polegają właśnie na dokonywaniu tego, co z perspektywy „porządku policji” (Rancière 2008) jest niemożliwe.

Tekst Joanny Rutkowiak stawia przed nami zatem zadanie przemyślenia czy wymyślenia na nowo instytucjonalnych ram, które brałyby pod uwagę efemeryczną i kontekstualną naturę kształcenia i dlatego umożliwiałyby dążenie do mgnieniowych, sporadycznych i skromnych osiągnięć, czyli umożliwiałyby osiąganie niemożliwego.

\section{Literatura}

Benjamin W., 2012, Przyczynek do krytyki przemocy [w:] idem, Konstelacje. Wybór tekstów. tłum. i red. A. Lipszyc, A. Wołkowicz, Kraków: Wydawnictwo Uniwersytetu Jagiellońskiego.

Manen M. van, 1991, The Tact of Teaching. The Meaning of Pedagogical Thoughtfulness, Albany (NY): State University of New York Press.

Rancière J., 1991, The Ignorant Schoolmaster. Five Lessons in Intellectual Emancipation, transl. K. Ross, Stanford (CA): Stanford University Press.

Rancière J., 2008, Na brzegach politycznego, tłum. I. Bojadżijewa, J. Sowa, Kraków: Korporacja Ha!art.

Zamojski P., 2009, Cynizm i donkiszoteria. Etyczne konteksty masowego kształcenia w szkole wyższej, „Teraźniejszość-Człowiek-Edukacja. Kwartalnik Myśli Społeczno-Pedagogicznej” nr 4 .

\section{Streszczenie}

W swojej odpowiedzi na artykuł Joanny Rutkowiak skupiam się na próbie rozumienia znaczenia analiz autorki dla konceptualizacji kształcenia. Idę tropem funkcji przemocy w tworzeniu równości, sporadyczności wydarzenia edukacji oraz rekonceptualizacji osiągnięć edukacyjnych.

\section{Słowa kluczowe}

Rutkowiak, Rancière, równość, przemoc, edukacja 


\section{Summary}

\section{Because things are fleeting one must have a trained eye}

In my response to the seminal article by Joanna Rutkowiak I focus on the consequences of the argument she puts forward for understanding education. I refer to the function of violence in making equality happen in the classroom, the sporadicity of the event of education, and a new understanding of educational achievements.

\section{Keywords}

Rutkowiak, Rancière, equality, violence, education 